\title{
ESTABLISHING MEDICAL EDUCATION UNIT (MEU) AND MEDICAL SKILL CENTRE (MSC) AT MEDICAL INSTITUTES IS THE DEMAND OF PRESENT TIME
}

\author{
MD HUMAYUN KABIR TALUKDER \\ Professor, Curriculum Development \& Evaluation \& Course Director, Centre for Medical Education (CME)
}

(Bangladesh J Physiol Pharmacol 2011;27(1\&2):28-30.)

\section{INTRODUCTION}

Competency' is: "a cluster of related knowledge, skills, and attitudes that affects a major part of one's job (a role or responsibility), that correlates with performance on the job, that can be measured against well-accepted standards, and that can be improved via training and development".

Competencies are gained through a multitude of easy- life experience; formal education; apprenticeship; on -the-job experience; self help programs; and yes, training and development programs ${ }^{1}$.

Some examples of competencies required by the employees are---adaptability, commitment, creativity, motivation, foresight, leadership, independence, emotional stability, analytical reasoning and communication skills.

Classification of competencies are, Core competencies, Professional competencies or functional competencies, Behavioral competencies, Threshold competencies, competency can be measured by behavioral-Anchored Rating Scales (BARS) \& Universal competencies ${ }^{2}$. Universal competencies are not bound within career field, Characteristics of Competency-based Medical Education is where the learning outcomes (competencies) are identified, performance based, and communicated to all $^{3}$.

\section{MATERIALS AND METHODS}

Different professional competencies/roles are as follows ${ }^{4}$ :

GMC Competencies are good clinical care, maintaining good medical practice, relationship with patient, working with colleagues, teaching and training and probity (Professionalism).

ACGME Competencies are patient care, medical knowledge, practice-based learning \& improvement,

Address for correspondence: Md Humayun Kabir Talukder, Professor Curriculum Development \& Evaluation \& Course Director, Centre for Medica Education (CME), Mohakhali, Dhaka, Bangladesh. Email: hktalukder@yahoo.com interpersonal and communication skills, professionalism and systems-based practice.

Can MEDS Roles are medical expert, (Clinical decision maker), communicator, collaborator, manager, health advocate, scholar and professional.

Saudi Meds Competencies are patient Care \& social accountability, approach to practice, doctor and patient, doctor and community, communication skills, doctor and research, doctor and IT \& Professionalism.

Provision should be at different institutes level to take care about the above mentioned competencies. Teachers should be acquainted and oriented locally about those time to time as they are the mentors for inculcating competencies among the students to produce them as future competent health workforces. MEU and MSC at institutes level can play an important role in this regards.

\section{Rationale}

At present there are total 33 postgraduate institutes, 23 govt. and 53 non govt. medical colleges and are 09 govt. and 14 non govt. dental colleges in Bangladesh $^{5}$. There are total 81 institutes of health technology (IHT), 96 medical assistants' training school (MATS), 82 diploma nursing institutes, 20 diploma midwifery nursing institutes, 19 basic BSc nursing colleges and 19 post basic nursing colleges in Bangladesh $^{6}$. Centre for Medical Education was established in 1983for teachers training and reviewing and updating of different curricula ${ }^{7}$. Since inception of CME it is trying it's best to train the teachers on educational science, teaching methodology, assessment \& evaluation, instructional materials development, curriculum development \& problem based learning etc. But it is impossible for CME alone to provide training for the teachers of different postgraduate institutes, govt. \& non govt. medical college, dental college, IHTs, MATS, nursing institutes and nursing colleges etc. There should be provision to train the teachers of respective institutes at own premises. Keeping this in mind initiatives were taken to establish medical education unit (MEU) \& 
medical skill center (MSC) in different medical colleges specially in old 8 medical colleges. Few of those are still partially functioning specially the medical education units.

At present Bangladesh is implementing discipline based curriculum with few scope of Community Based Teaching Learning (CBTL) having the provision of core \& optional content based curriculum. The products of present MBBS \& BDS curriculum are possessing lots of knowledge \& theory. But different studies revealed that the products are not competent enough clinically to serve the diseased people as well as they are not competent enough in regards to generic competencies. For the modern world WHO is suggesting to produce. "Five Stars Doctors" having the qualities \& competencies as a manager, decision maker, communicator, leader \& care provider $^{8}$. Except the qualities \& competencies of a care provider still which is questionable on reality the product of the MBBS \& BDS course do not have generic competencies regarding the events related to Five Star Doctors' up to the mark. But on reality the doctors are the team leader in the service providing ground who have to communicate, manage, lead and to take decision at the right time. As they are not taught and oriented at all in their formal MBBS \& BDS course about these generic competencies. These generic competencies are the foundations of care providing. So for effective delivery of the health care \& nursing services the medical, dental, medical technology \& nursing students should be taught, oriented, demonstrated on those competencies. To acquire those competencies provision of hands on training, role play, simulation, standardized patients practices \& demonstration should be there. For effective conduction of those sessions it is very important to identify the competencies in the context of different subjects, considering the need of the society \& future job description which to be performed by the future graduate doctors.

The Network Medical Councils of South East Asia (SEA) region is promoting the councils of this region to give due importance regarding patient safety and competency based medical curriculum. Bangladesh is a signatory of that agreement to promote competency based curriculum to ensure patient safety ${ }^{9}$.

In such a situation it is very time felt need to develop medical education unit and medical skill centre identifying the competencies and also considering their job description.

\section{Outline of Medical Education Unit ${ }^{10}$}

- The Medical Education Unit is intended to be educational resource centres for Medical College teachers and students. The aim of the MEUs, which are essentially a human resource consisting of a nucleus of faculty, is to bring about a continuing improvement in medical education, at the institutional and the national levels, in keeping with the changing health needs of the country.

- $\quad$ The Medical Education unit should have trained manpower on medical education, Audio visual expert, computer operator and support staff.

- Physically they consist of office accommodation, a meeting area, and storage space. They are equipped with computers, printer, multi media projectors, OHP, screen, Photocopier, scanner, video, digital camera etc. facilities and equipment for the production of educational media, as well as teaching equipment and learning materials which can be made available to teachers for use in their departments.

- The Medical Education Unit most important function will be to act as a meeting place where innovative educational ideas can be debated, developed and disseminated, and where educational meetings can be held to orient new teaching staff and provide updates for existing staff.

- $\quad$ The Medical Education Unit will have strong professional linkages with other Medical Education Unit and with the Centre for Medical Education (CME), Mohakhali, Dhaka. It is rather hoped that active members of the Unit will participate in the Centre for Medical Education (CME)'s activities and in that way contribute to the national development of medical education.

\section{Objectives of Medical Education Unit:}

1. Undertake faculty development to enable teachers to play their role as educators and promoters of medical education more effectively.

2. Enhance appropriate use of media.

3. Improve the system of assessment

4. Conduct educational research in particular, in assessing the relevance of the undergraduate curriculum in meeting the community health needs.

5. Undertake planning and development of appropriate curriculum.

6. Develop, procure and share learning resource materials (LRMs) and serve as a resource centre. 
7. Conduct courses for students on subjects such as communication skills, managerial skills, health ethics and behavioral science.

8. Collaborate with the Centre for Medical Education, Mohakhali, Dhaka and the medical education units of other medical institutes as partners in a nation-wide effort for improvement in medical education in the country.

\section{Outline of Medical Skills Centre ${ }^{11}$}

- A Medical Skills Centre (MSC) is a purpose built teaching area within the Medical College for the teaching of practical skills to medical students. An essential component is that it has a good supply of equipment and models on which the students can practice, and an environment conducive to the structured teaching of skills. There are also private areas for conducting clinical examinations.

- For the proper learning of practical skills (psychomotor skills, cognitive skills \& affective skills) the student must fist watch a demonstration of the skill and subsequently practice under supervision and then independently.

- The Medical skills centre should have trained manpower on medical education, equipment operator, computer operator and support staff.

- $\quad$ The MSC provides a suitable physical environment and the equipment (dummy, model, simulated machineries \& simulated patients) needed for learning these skills.

- The MSC provides an environment conducive to the initial teaching and practicing of clinical skills, communication skills and technical skills involving the handling and use of diagnostic instruments and medical equipment. With video recording and playback equipment the MSC can also help to improve communication skills.

- $\quad$ The MSC allows students to practice and perfect a skill before they perform it on patients in the wards.

- $\quad$ At each MSC one teacher as facilitator of the MSC and an equipment operator have had training in the use of the equipment and can provide help as required. A trained store man should be also available to handle, clean and store equipment.

\section{REFERENCES}

1. Universal Competencies Home Page. What is competency-based training (www.nps.gov/training/uc/whauc.htm).

2. Universal Competencies Home Page. Why have Universal competency? (www.nps.gov/training/uc/whauc.htm).
3. Universal Competencies Home Page. What are the Universa Competencies? (www.nps.gov/training/uc/whauc.htm).

4. Supervision, Training Monitoring and Assessment in Postgraduate Residency Program of Bangabandhu Sheikh Mujib Medical University. Professor Mohammad Nazrul Islam, Cardiology, and Course Director, Faculty of Medicine, BSMMU, Dhaka.

5. Medical Education, DGHS, DGHS-August-2012.

6. MHK Talukder, Medical Education in Bangladesh, Bangladesh Medical Journal, 2012, vol 41, no 2, pp.7.

7. Amin Z, Merryless N, Hanif A \& Talukder Humayun Kabir. Medical Education in Bangladesh, 2008: Medical Teacher, 30:243-247.

8. General Medical Council, Tomorrow's Doctors, December, 1993.

9. Talukder Humayun Kabir, Report on "Identifying Competencies for Undergraduate Medical Curriculum- Teachers' Views" June 2012.

10. The functional development of the medical education units of the medical colleges, Further Improvement of the Medial Colleges in Bangladesh, November, 1995.

11. Medical Skills Centre, Further Improvement of the Medial Colleges in Bangladesh, 1996. 